\title{
Italy and Mozambique: Science, Economy \& Society within a History of an Anomalous Cooperation
}

\author{
Luca Bussotti ${ }^{1}$, Antonella De Muti ${ }^{2}$ \\ ${ }^{1}$ Centro de Estudos Internacionais ISCTE-IUL, Lisbon, Portugal \\ ${ }^{2}$ Federal University of Minas Gerais, Belo Horizonte, Brazil \\ Email: Lbiau@iscte.pt, antonellademuti@yahoo.com
}

Received November $18^{\text {th }}$, 2013; revised December 19 ${ }^{\text {th }}$, 2013; accepted December $26^{\text {th }}, 2013$

\begin{abstract}
Copyright ( 2013 Luca Bussotti, Antonella De Muti. This is an open access article distributed under the Creative Commons Attribution License, which permits unrestricted use, distribution, and reproduction in any medium, provided the original work is properly cited. In accordance of the Creative Commons Attribution License all Copyrights (C) 2013 are reserved for SCIRP and the owner of the intellectual property Luca Bussotti, Antonella De Muti. All Copyright (C) 2013 are guarded by law and by SCIRP as a guardian.
\end{abstract}

\begin{abstract}
In this article the authors aim at showing how an "anomalous" international and very intense cooperation between Italy and Mozambique was born. In fact, Italy has not a strong colonial tradition, especially in Mozambique, so it seems interesting to try to understand the reason why this former Portuguese colony has become the Italian most important partner in its cooperation activity. This analysis is based on the main hypothesis related to the birth of international bilateral cooperation: they have been seriously considered in order to explain the origin of this strange relationship, but they cannot completely clarify this particular case. According to the Italian social and political recent history, the privileged relationship with Mozambique is due more to a "bottom up" process than to geo-strategic or economic reasons. The fact that Mozambique had belonged to a weak Western power such as Portugal certainly gave Italy the opportunity to penetrate more easily in this country than in the ones which had been under the strong dominion of France or England. One of the most important results of this "anomalous" cooperation has to be found in the scientific fields (such as geology, architecture, biotechnologies) and in its impact on the development of Mozambique.
\end{abstract}

Keywords: Italy; Mozambique; Bilateral Cooperation; Origins; Comparative History; Institutions; Science; Economy \& Society

\section{Introduction}

This study aims at understanding why and through which modalities the cooperative relationship between Mozambique and Italy has taken its exceptional character and lasting commitment.

Even though its first cooperation Act was only passed in 1979, Italy got involved in cooperation activity with Mozambique since the years of the liberation struggle and the period immediately after the independence of this former Portuguese colony (1975).

Indeed, it seems difficult to explain how such an intense relationship was born, since even the brief Italian colonial experience was far from being in Mozambique, having concentrated, at the level of sub-Saharan Africa, especially in Ethiopia and Somalia. However, Mozambique is, up to now, the favorite destination of the official development assistance (ODA) from Italy, the eighth world power.

The answer to such a question, in fact, appears to be substantially different from the one that can be given for the European countries with strong colonial traditions. Actually they established, in Africa as elsewhere, "natural" cooperation relations with the newly independent countries because of the previous ties to their former political domains. This has resulted, in the majority of cases, in extensive partnerships. Let's consider, for example, France, whose former colonies have been influenced in financial, monetary, cultural, economic and even military terms, as recently demonstrated by the case of Mali. As Gabas pointed out, the priority of France cooperation has always been to establish a "Francophony-Africa-Mediterrean trio"; its image continues to be that of a country strictly linked to its colonial past (Gabas, 2005: 249). The relationships between the UK and its former african colonies were based, for a long time, on the “imperial” Britannic vision; even after decolonization, during the 1950s and 1960s, "the prevailing economic models emphasized investments” (Paquement, 2010). Much more problematic have been the relationships between Portugal and PALOP (Moita, 1985; Ferreira, 1994), Spain and Equatorial Guinea (Velloso, 2007), Belgium and Congo (Gerard-Libois, 1970; Vanthemsche, 2012).

Nothing similar can be said as regards Italy, substantially free of a colonial past, and whose foreign politics have always been characterized by a sort of "international equilibrium" between its Atlantic position (NATO membership and close relations with the USA), the European and Mediterranean vocation and the search for a dialogue between Israel and Palestine (Puri Purini). These options changed in 2001, when Berlusconi and his Government made stronger relations with Bush's Unites States and Putin's Russia, reducing his commitment in Europe. The African perspective has never been a priority for Italian Government. 
In recent years Berlusconi has developed a favoured relation with Ghaddafi and, in the Middle East, with Israel, instead of encouraging the dialogue with the Palestinians.

For this reason, the answer to the basic question about why Mozambique is the main objective of Italian ODA, will also allow us to reject models that are, perhaps, too often taken for granted, but that cannot apply to the case here analyzed. The reference is to that model of the international Western cooperation with the developing countries, first of all the American one, whose key features are rooted in the European Recovery Program (ERP) or Marshall Plan. The ERP was launched immediately after the Second World War in order "to help" those European Countries (such as Italy) whose industrial apparatus had been dramatically destroyed and which had to enter the forum of "democratic" nations (Truman doctrine). The same principles-economic growth and democratization, according with a "top-down" approach and an accentuated bilateralism instead of multilateralism-oriented the birth and the goals of USAID (created in 1961), a powerful "Cold War" instrument against the Soviet Union in the area of developing countries. Despite clear differences, the politics of international cooperation carried out by the European Countries most engaged in this activity (the Netherlands, Sweden, Norway, etc.) have to be embedded in the same globalized context, in which the principles of Western democracy and free market had to constitute the new pillars of the former European colonies in Asia and Africa. For these reasons this kind of cooperation has been the target of several criticisms over the years, almost all of them from the point of view opposite to the liberal conception, or even of Marxist tendency, from the Dependency Theory to the current positions of an economist like Jeffrey Sachs (Frank, 1966; Cardoso \& Faletto, 1979; Amin, 1977; Grieco, 1988; Sacks, 2005).

Through this research we get to the conclusion that other channels have been used to develop the special relationship between Italy and Mozambique. This is due to three key factors: first, the permanent pressure from the Italian "civil society" on its politicians; second-paradoxically - the lack of a clear Italian strategy in its international and African politics which allowed the acceptance-from a political perspective-of Mozambique as the priority country for international Italian cooperation. Finally, a geo-political reason, since Mozambique had been colonized by a weak European power such as Portugal, which, on its leaving, left a vacuum in which the Italian ambitions were able to fit. So, it is possible to say that, the building of bilateral relations between Italy and Mozambique was initially rooted in "informal" mechanisms, and only subsequently was institutionalized at a formal level.

This article consists of three parts: in the first, a summary of the main lines of the development of the Italian cooperation both in general and with Mozambique will be presented, accompanied by essential statistical data; in the second, we will try to formulate hypothesis in order to understand why Italy chose Mozambique as its main cooperation partner; finally, we will show the conclusion of our research.

In terms of methodology, the research has been based on a number of sources: the official ones, published by the Italian Foreign Ministry, the archives of the Ministry itself in Rome, testimonies on the birth of the cooperation relationships between the two countries (on the Italian side as well as the Mozambican), the available bibliography, though not too wide.

\section{Mozambique in the Italian Cooperation}

\section{The Birth of Italian International Cooperation}

After the end of the Second World War, Italy was in quite difficult conditions. The Country had to be almost completely rebuilt, especially in the North, where the largest part of its industrial apparatus was concentrated. So, from 1945 to 1960, the efforts of the Italian politics were focused on internal targets more than on foreign policy. Moreover we have to remember that Italy was a "losing power", and had a low international credibility. In addition to this, according to the reasons above mentioned, Italy entered NATO in 1949 notwhistanding the hard political battles led by the Communist and the Socialist Parties inside and outside the Parliament, and only in 1955 joined the United Nations. It is now easier to understand the reason why, differently from what happened for the other European powerful States, Italy began to deal with cooperation with developing countries very late.

The first steps of the Italian Government in the international cooperation were 1) to manage the relations with Somalia, a former colony, of which Rome had had the fiduciary administration until 1960; 2) The approval of two laws (the No. 1033/1966 and the No. 75/1970) regarding the international volunteer service, with the aim to give technical assistance to developing Countries; 3) The approval of the Law 1222/1971, the first specifically directed to the international cooperation, with a budget of 50 billion liras in 5 years. Once more, it was not a law dealing with all the aspects of international cooperation, but an act which aimed at regulating the activity and the legal status of public servants working in the technical cooperation with the developing countries, giving special provisions to Somalia. According to Gallizioli, because of the lack of a clear strategy of its international (and African) politics, $80 \%$ of the budget went to fatten the bureaucracy of the international organizations. Between 1971 and 1979 the private fluxes for International cooperation overcame the public ones (Gallizioli, 2009).

This first phase of the Italian international cooperation was characterized by a total confusion in terms of institutional competence: the funds for Somalia administration were managed by four ministries and the Italian Central Bank. The total budget for Somalia was of 90 billion liras (about 50 million euro) in the 1950s and of 60 billion liras in the following decade. The confusion can be explained by the fact that Italy hadn't decided yet whether to include this activity inside the structure of the Ministry of Foreign Affairs or to create an external agency.

A new phase began with the approval of the law 38/1979, following to which a Department for the Cooperation to Development was created within the Ministry of Foreign Affairs. It is possible to affirm that the 1980s were the "Golden Age" of international Italian cooperation.

The last phase began with the approval of the law 49/1987, which stated that the cooperation for development was part of Italian foreign policy (art. 1). In this period (1989), Italy reached its maximum in terms of ODA ( $0.41 \%$ of the GNP), differently from what was happening in the other European countries. The increase of ODA, in percentage, was relevant, passing from $0.08 \%$ to $0.19 \%$ of GNP over the two first years of the 1980 s, reaching $0.35 \%$ in 1984 . In 2003 not even $0.20 \%$ of the GNP was invested in international cooperation, leaving Italy at the last place in Europe and the second lowest position inside OSCE. 
This downward trend continued in the 2000s, when the budget for the ODA passed from 732 million euro in 2008 to 86 in 2012.

As the Minister for Cooperation and Integration, Andrea Riccardi, said in December 2011:

The Italian aid for development is stagnant. We are far from the European objective of 0.5 per cent and 0.7 per cent of the UN. Last year we reached a historic minimum ( 0.15 percent of GDP) ending in second last place in the ranking of donors, only followed by Korea. For 2012, the forecast is for a further decrease $^{1}$.

Italy started from these "institutional” bases and didn't have a clear strategy, but even though Mozambique has constantly represented the priority country for the Italian international cooperation. In order to explain the reason and the way in which this "anomalous" cooperation has been improved along the years, it is necessary to investigate outside the institutional level. The hypothesis which can be formulated is connected with the ability of the Italian "civil society" to influence the Italian government at making the cooperation with Mozambique a priority in its African politics.

\section{The Position of Mozambique in the Italian ODA}

After many years in which its resources were distributed to a large number of countries, the Italian Cooperation accepted the recommendations of the OSCE/DAC Peer Review 2004, Note for programming guidelines $2007-2009^{2}$, deciding to focus its aid on the Sub-Saharan African countries and on those in postconflict situations (DAC, 2009). In addition, the various geographical areas were assigned two different levels of priority, and the aid was addressed to the areas of health, education, environment, alternative and renewable resources, public and global good and gender equality (DAC, 2009).

Mozambique, which has been assigned priority level 1, has, so far, firmly maintained the privileged position it has enjoyed since its independence (Development CO, 2012).

From 1982 to 2009, this country received $€ 764$ million in grants and loans of which 105.9 million euro in aid credit; to these figures it must be added the resources arising by debt cancellation in 2002, amounting to 557.3 million euro (IDEM). Mozambique has also been selected, the only one among all the countries supported by the Italian Cooperation, for the implementation of a project for direct support to the state budget, the Budget Support, and chosen, along with Vietnam, as the target country for twinning business.

In the reports published by the Italian Cooperation, we read:

Over the past five years, the aid from the Italian Cooperation in sub-Saharan Africa was more than 1000 million Euros, targeted to interventions involving a total of 34 out of the 46 countries in the region. The main beneficiaries of the aid have been Mozambique, Ethiopia and Sudan.

In 2010, about 54 million were released as gift (spread over 34 countries and recipients) while 10 million euros were granted

\footnotetext{
${ }^{1}$ Conference in the occasion of the 40th anniversary of IPALMO, 1971-2001: "Ieri, oggi domani, quattro decenni di trasformazioni geo-economiche-politich", speech by the Minister for International Cooperation and Integration Andrea Riccardi, Rome December 12th, 2011.

http://www.integrazione.gov.it/ministro/discorsi/2011/12/conferenza-ipalmo -anniversary.aspx, accessed January, 2012.

${ }^{2}$ DIPCO $14 / 2007$ it is the weekly bulletin of the DGCS (General Direction for Development Cooperation) in which all the resolutions of the general manager and the executive committee, as well as notices, documents and international reports are recorded.
}

in aid credit.

Mozambique was the largest recipient of Italian aid, with 21 million provided in 2010, followed by Somalia (10 million), Ethiopia (8 million), Sudan (7,000,000). Other beneficiary countries were Kenya, Uganda and Senegal ${ }^{3}$.

The action of the Italian Cooperation in Mozambique started immediately after its independence and continued, without interruption, until the present day, despite relevant reductions.

Due to the development of its political-economic situation, supported by its institutional stability, Mozambique seems to represent a virtuous case in the much criticized system of international cooperation (Carrino, 2005), that was able, in this case, to transform the emergency humanitarian aid (during the bloody civil war that swept the country until 1992) in real development cooperation (World Bank, 2008).

Mozambique always appears at the forefront of Italian ODA. Tables 1 and 2 indicate the main Italian bilateral aid recipient countries from the years 1987-1988 until the years 2008-2009, from which it is evident its privileged position, similar, but often even more favored than that of Ethiopia, a former Italian colony.

In recent years, following the evolution of the international geopolitical frame in which the Italian interests are located, new priorities have arisen as for the allocation of the resources. The new situation has led to the displacement of urgent interventions in conflict and crisis areas, especially after the changing of the balance on the world stage, such as the dissolution of the Soviet Union, the Balkan war (1991-1995) the Afghan conflict (2001) and the Iraqi (2003-2011), the lasting instability on the Middle East chessboard, the explosion of migration flows.

\section{The "Strange" Birth of a Cooperative Relationship: Hypothesis}

The reason for such a large commitment in men and resources of the Italian cooperation in that distant country in Sub-Saharan Africa rises interesting questions, which we will try to answer through the analysis of what the general motivation of the ODA allocation are considered to be, trying to assess the extent to which Mozambique meets the criteria that are placed at the basis of the interventions, categorized as follows (Isernia, 1995; Raimondi/Antonelli, 2001):

1) geo-economic reasons: they presuppose economic implications resulting from the geographic proximity, as was the case with the support of Italy in countries such as Albania, the former Yugoslavia or the African Mediterranean countries;

2) political-economic reasons: they appear when an industrialized state does not intend to have relationships with a developing one for political-ideological reasons (US cooperation with some "rogue states" through Japan);

3) international political motivation: they arise from the relevance of geo-political unstable areas or places of conflict that represent a threat to world peace (see Iraq and Afghanistan);

4) post-colonial motivation: industrialized countries concentrate their aid in their former colonies, to help their growth;

5) economic motivation: it is a form of cooperation from de-

${ }^{3}$ For information about the financial commitment of the Italian cooperation for development, see: A. Raimondi, G. Antonelli, op. cit. See also the annual reports on the implementation of the policy of development cooperation on the site.

http://www.cooperazioneallosviluppo.esteri.it/pdgcs/italiano/Pubblicazioni/i ntro.html 
Table 1.

Italian ODA (1987-1998) values expressed in millions of US dollars.

\begin{tabular}{cccccc}
\hline Countries & Tot & Countries & Tot & Countries & Tot \\
\hline 1987/88 & usd & $1992 / 93$ & usd & $1997 / 98$ & usd \\
Mozambique & 266 & Mozambique & 195 & Madagascar & 67 \\
Somalia & 268 & Tanzania & 199 & Mozambique & 65 \\
Ethiopia & 233 & China & 166 & Haiti & 44 \\
Tanzania & 174 & Egypt & 141 & Uganda & 40 \\
China & 136 & Argentina & 144 & Ethiopia & 39 \\
Tunisia & 104 & Tunisia & 103 & Malta & 24 \\
Sudan & 97 & Morocco & 89 & Albania & 22 \\
Egypt & 94 & Sierra Leone & 100 & Argentina & 20 \\
India & 63 & Ex Yugoslavia & 91 & Ecuador & 20 \\
Senegal & 59 & Albania & 81 & China & 20 \\
\hline
\end{tabular}

Source: Raimondi/Antonelli, 2001.

Table 2.

Italian ODA (2002-2009) values expressed in millions of US dollars.

\begin{tabular}{|c|c|c|c|c|c|c|c|}
\hline Countries & Tot & Countries & Tot & Countries & Tot & Countries & Tot \\
\hline $2002 / 03$ & usd & 2006 & usd & 2007 & usd & 2008/09 & usd \\
\hline Mozambique & 231 & Nigeria & 755 & Iraq & 480 & Iraq & 429 \\
\hline Rep Congo & 225 & Iraq & 485 & Morocco & 83 & Afghanistan & 92 \\
\hline Tanzania & 67 & Serbia & 129 & Ethiopia & 105 & Ethiopia & 60 \\
\hline Ethiopia & 48 & Ethiopia & 105 & Lebanon & 65 & Palestine & 55 \\
\hline Tunisia & 35 & Cameroun & 63 & Afghanistan & 62 & Lebanon & 48 \\
\hline Guinea Bissau & 35 & Zambia & 51 & Sierra Leone & 44 & Albania & 43 \\
\hline Afghanistan & 33 & Lebanon & 44 & Mozambique & 43 & Liberia & 38 \\
\hline China & 31 & Afghanistan & 32 & China & 42 & Ivory Coast. & 34 \\
\hline A.N.P & 26 & Mozambique & 30 & $\begin{array}{l}\text { St. Vincent } \\
\text { \& Grenadine }\end{array}$ & 41 & Mozambique & 30 \\
\hline Albania & & Albania & 30 & Serbia & 23 & Sudan & 27 \\
\hline
\end{tabular}

Source: OSCE/DAC, Peer Review, Italy, various years.

veloped countries, aimed to achieve specific economic dividends, especially favoring their own business in the underdeveloped countries, and exploiting its natural resources.

In the case of the relationship Italy-Mozambique, the first three points are evidently to be rejected a priori. We will focus, therefore, on the last two, particularly on point 4.

Post-colonial reasons: In our opinion, a first, possible answer for the massive Italian commitment in Mozambique can be sought in the establishment of "political" non-governmental relations among some leaders of political parties and organizations in Italy and Mozambique.

In this first case, Italy, after trying to implement its foreign policy and cooperation in its former colonies, with which, however, didn't succeed in maintaining strong ties, turned to the territories "belonging to weak colonial powers because the relationships with the other countries belonging to former strong colonial powers were essentially precluded" (Calchi Novati, 1997).

This opinion was substantially shared by Ennio Di Nolfo, according to whom:

As a matter of fact, Mozambique, like other Portuguese colonies, was one of the privileged sectors of the Italian penetration, being Portugal a weak power, so having Italy the possibility or hope to get more benefits than those which could be obtained from other colonies belonging to France or Britain) (Di Nolfo, 1997).

Therefore, Italy probably intended to create its own area of political and economic influence in a country of ancient Portuguese colonization that, even from a geographical point of view, was closer to its former colonies and had reached independence in the period in which Italy had just begun to structure its cooperation policy.

Another important element to be taken into account was the conditioning resulting from the commitments arising from its participation in the Atlantic Pact. How it makes us keenly note Calchi Novati:

NATO, and in general East-West policy, gave Italy the opportunity to intervene much more on the world stage. Among other things, being accepted among the great liberal democracies of the West was considered itself a foreign policy objective, indeed the only true big goal attained by our foreign policy (Calchi Novati, 1997).

Even after the ending of the "bloc politics", the influence of the Atlantic Alliance has remained strong. Italy has therefore tried to take advantage of the conflicts within the NATO (Romano, 2002) to recover those positions that were closer to his original interest, and had partly to set aside due to its dependence from the ally (Calchi Novati, 1997). The Italian support to Mozambique in the period when the country was a Socialist Republic, can be placed in this perspective.

The one above described, however, represents the already "institutionalized" phase of the cooperation between Italy and Mozambique. The question that now arises is how these results were reached. "Political non-governmental relations" played in this case a decisive role. They came before the strategic options in the "official" Italian foreign policy were taken, but then they facilitated its implementation and consolidation. Here is what the first Italian ambassador in Maputo, Claudio Moreno (in office from 1976 to 1980), protagonist of the events of those years, says: The friendship with Mozambique was born through the thin network of diplomatic contacts woven by Italy, which led to the opening of the first embassy of a Western country in Maputo.

\section{The Role of Italian Political Organizations and Civil Society in the Birth of Bilateral Cooperation Italy-Mozambique}

Moreover, Italy was one of the first Western countries to promote a joint committee and a cooperation agreement with Mozambique. Moreno also emphasizes the important role that the pressures and initiatives on the government by the PCI and the PSI had in order to encourage the birth of the Italian development cooperation with Mozambique.

The above presented situation suggests that, in the decade 1970-1980, at least three social actors were able to influence the institutional choices in favor of Mozambique. They are the mirror of the Italian political peculiarity in the context of the Cold War. Actually, Italy was a country in which the socialist and the catholic traditions worked together for the building of popular democracy and international stability. These two ten- 
dencies were not only of political nature: they were of cultural, ethical, philosophic nature too. Their different ideas of solidarity made a convergence of interests towards Mozambique that was possible, thanks to other, important international reasons, too, that we will present later.

The most significant forces that contributed to the choice Mozambique as the privileged Italian international partner are the following:

The left wing parties, both in their direct relations with the Central Government and in those with the local governments, especially in the so called "Red Towns" (towns with a left wing local government); which represented the first example of decentralized cooperation.

The Catholic Church, especially through some of its organizations, which were able to influence the Christian Democrat Party (DC) in power, in order to develop good relations with Mozambique, in addition to NGOs of different inspiration;

Italian academic world, widely present from the beginning of the Italian cooperation with Mozambique, and even more after the failure of the Somali experience in the 1980s.

1) If in the "First Republic" the left wing parties never had direct responsibility in central government, the same cannot be said with regard to local governments that gave a decisive contribution to cooperation with Mozambique ${ }^{4}$. Although there isn't a wide literature on the subject, with the exception of very few studies (Lanzafame/Podaliri, 2004), we can find a large numbers of contributions of journalistic or propagandistic nature, as well as the testimonies of those who lived in the first person that extraordinary season that can help us to rebuild the development of this unique relationship. The first contacts between members of the political and intellectual Italian and Mozambican worlds took place in the early sixties. At that time, a strong anti-colonial attitude and a feeling of solidarity with developing countries had developed in the Italian public opinion, involving more and more sectors of the society: from intellectuals, to the Church, from organizations of various kind to students as well as ordinary people. This attitude spread to the institutions, giving impulse to a series of initiatives of solidarity from cultural, religious and political forces even before an interest by the government was born (Calchi Novati, 1997). Dina Forti, for many years responsible for the contacts with the liberation movements in developing countries on behalf of PCI, tells that in 1962, two years before the declaration of armed struggle, was contacted by Marcelino dos Santos, one of the main leaders of FRELIMO, of whom she had never heard about. Dos Santos asked her to arrange a meeting with one of the PCI leaders to talk about Mozambique and the rising of its independence movement. Giancarlo Pajetta, head of the International Department, agreed with great interest to meet him $^{5}$. At the time, many Italian municipalities as Piacenza, Grosseto and Trento gave their support to the anti-colonial struggle In October 1964, the Reggio Emilia communist ruled city council, following the FRELIMO decision to start the armed insurrection, sent to the guerrilla leaders a message of support to the liberation struggle of the people of Mozambique. A few years later, in 1966, José Luís Cabaço, a young FRELIMO activist, who later held important government positions, arrived in Italy with two objectives: to study sociology

\footnotetext{
${ }^{4}$ Interview with Ambassador Claudio Moreno, 28th January 2011.

${ }^{5}$ Some information are taken from our meeting with Dina Forti, that took place in her house in Rome on 26th January 2011; She recalled some events very clearly, others she had forgotten because of the old age or she preferred not to talk about. We have only used information that could be confirmed.
}

at Trento University and create a network of relationships that might have helped in the fight against the Portuguese colonialism: the objective was actually met. Although he never directly took part in the commissions dealing with cooperation, the Mozambican statesman became an adviser to the Foreign Minister Joaquim Chissano and President Samora Machel for issues concerning Italy, because of his deep knowledge of the country ${ }^{6}$. So Luis Cabaço recalls the climate of fervor and renewal that Italy experienced in the Sixties and Seventies:

It is not possible to understand the cooperation between Italy and Mozambique if we do not remember the peculiarity of the Italian democracy in the post war period, its partisan tradition and, in particular, the dream of a historic compromise between the Catholic and socialist positions as regards social justice. With the advent of anti-colonial struggle, the means of communication between our two peoples expanded the missionary experience, incorporating components of political identity which took off from the hands of the Portuguese colonial government its control on this relationship. This spaces opened the way to the first interventions of a Catholic Church committed in favor of the destiny and the aspirations of colonized people... Also the role played by the political left winged forces on the issue of the Third World grew (Cabaço, 2003: 9).

It was in this atmosphere that the idea of organizing a conference of solidarity with the peoples still under the Portuguese colonial rule arose. It was held in Rome from 24 to 26 June 1970 and was attended by representatives of Angola, Guinea Bissau and Mozambique. Personalities belonging to the world of culture and politics from all the parties gave their support to the event. On this occasion, an official meeting between representatives of the Portuguese colonies and Pope Paul VI was arranged. It had a great importance since it represented the legitimacy, from a political and moral point of view, of the national liberation movements in those countries. The meeting with the Pope was organized by Marcella Glisenti, founder of the bookstore Paesi Nuovi in Rome, who had always been interested in issues linked to the Third World. Paesi Nuovi was connected to the DC, but, at the same time, Marcella Glisenti was part of IPALMO, whose President was Gian Paolo Calchi Novati, an academic professor of left tendency. This meeting represented the most effective initiative arising from the alliance between the democratic Catholicism and the Marxist tradition in favor of the liberation struggle of the African Portuguese colonies. In an indirect form, the European enemy was represented by Portugal, a State member of the NATO, but that did not collect any political sympathy in the main Italian parties. The political leaders who took part in the event were the leaders of the movements fighting for independence: Agostinho Neto from Angola, Amilcar Cabral from Guinea Bissau and Marcelino dos Santos from Mozambique:

...They were received as representatives of Angola, Mozambique and Guinea Bissau, so indirectly recognized as independent countries and not as Portuguese colonies. That caused, of course, the official protests of Portugal... (GLISENTI, 1993: 14).

Another important consequence of the Rome Conference was the birth of the "policy of twinning", chiefly supported by the eminent parasitologist Silvio Pampiglione, a doctor known for

${ }^{6}$ Interview with L. Cabaço, former State Work Secretary and acting Minister of Information in the transitional government, Minister of Transport and Communications (1 Government), Minister of Information 1981-1986, and Member of Parliament (Maputo November 29 2010 ). 
his humanitarian commitment in countries emerging from colonialism. It is so possible to say that the academic cooperation with Mozambique has its origin in this meeting: as a matter of fact, Pampiglione will be one of the first doctors to go to Mozambique, developing the first Italian cooperation programs.

So, in the same year 1970, the PCI entrusted three Italian cities councils with the task of managing relations with the three African countries: Angola was assigned to Prato, Guinea Bissau and Cape Verde to Arezzo and Mozambique to Reggio Emilia.

While the twinning projects with the other two cities did not produce lasting fruits, the one between Reggio Emilia and Mozambique remains one of the most meaningful and successful model of what was called "diplomacy from below" (Lanzafame/Podaliri, 2004: 15) the first example of decentralized cooperation. Even today there are cases of cooperation carried out at the level of local government: it is worth remembering the Cooperation Agreement between the Autonomous Province of Trento and the Province of Sofala in 2001.

About the twinning with Reggio Emilia, Giuseppe Soncini, then president of the Hospital Santa Maria Nuova in the city, said that he was contacted by the direction of the Communist Party who entrusted him with the task of creating a link with Mozambique. He confesses that, fascinated by the personality of Amilcar Cabral, would have preferred to deal with Guinea Bissau, but he accepted the Party guidelines, succeeding in giving birth to an unique and very successful experiment, one of the most striking examples of the involvement of local authorities: a partnership between the Reggio Emilia hospital and the guerrilla hospital, only a few huts in the Mozambique forest.

In 1972, Soncini organized an expedition across the border of Tanzania, to the northern areas of Mozambique freed by the guerrilla, to bring solidarity and concrete help. Besides him, other people took part in the expedition: Lanfranco Turci head of the Department of Health of the Emilia Romagna region, Angelo Pisi, vice mayor of Reggio Emilia, journalist Marisa Musu and Franco Cigarini, a photographer and documentary film maker on behalf of Reggio Emilia city council. The film Ten days with the guerrillas in freed Mozambique, shot by Franco Cigarini, remains as an evidence of the expedition. It is the first documentary movie on the liberation struggle in Mozambique that arrived in Europe 7 .

From 24 to 25 March 1973 the "National Conference of Solidarity with the struggle of Independence of Angola, Guinea and Mozambique" to which Samora Machel took part, was held in Reggio Emilia. Also this conference was supported by a large number of Italian politicians and intellectuals belonging to various political groups, such as PCI, PSIUP, PSI, DC.

During these meetings, the foundation of the friendship between the Italians and the representatives of the guerrillas, later rulers of Mozambique, was laid; a friendship that remained unchanged over the years. Among other measures in favor of Mozambique, the municipality of Reggio Emilia organized, from 1979 onwards, the sending of three cargo ships carrying humanitarian aids.

After independence, President Samora Machel personally invited Dina Forti in Mozambique with the delicate task of holding an institutional position on behalf of the government, thanks to

\footnotetext{
${ }^{7}$ A testimony about the expedition from Reggio Emilia to the guerrilla camps has been given by William Turci, Lanfranco Turci's brother, in a conversation in Maputo, where he moved in the period immediately following the independence, working for the Italian cooperation at first and then becoming an entrepreneur (November 2010).
}

the relations of friendship and respect that he and the leaders of FRELIMO had for her.

The Catholic Church has always considered Mozambique as an important target of its mission. It is quite impressive the number of articles, reports, interviews that the newspaper of the Italian Catholic bishops, "L’Osservatore Romano”, published since Mozambique independence. Although the majority of the articles are concentrated in two years, (1988: the visit in Mozambique of the Pope; 1992: the General Peace Agreement in Rome, thanks to the mediation of the Sant'Egidio Community), the activity of the Church in Mozambique is constantly reported with a very special attention by the newspaper (BUSSOTTI, 2011). When Samora Machel died, in 1986, although his clear anti-religious tendencies, "L'Osservatore Romano" commented the event in a very worried tone, because of the strategic transformation that Machel had been operating in the economic politics of Mozambique (Chillà, 1986). Many of the DC politicians, who took part in various Italian Governments, were strictly linked to the Church, especially to the missionary wing, particularly sensitive to the Mozambican reality. Among the politicians already mentioned, Piero Bassetti, Luigi Granelli (who occupied the charge of Minister), Carlo Fracanzani (who was Vice-Minister), were the exponent of this "missionary wing” in the Italian Government. Of course, they directly influenced the option for Mozambique, especially in the 1970s, when, in Italy, for the first and last time in its history, DC and PCI formed a government of national unity (1976), in order to fight the common struggle against terrorism. Coincidentally, these are the years in which Mozambique reached its independence, so it was quite easy, for the DC politicians, to comply with the requests coming from the PCI and the Catholic Church. Even if the Italian government never recognized the FRELIMO during the national liberation struggle, Mozambique was officially recognized immediately after its independence. Hence, the Italian central authorities began the building of an aid program. What had happened in the two meetings in Rome and Reggio Emilia helped in this sense: Minister Fanfani agreed, for example, to meet President Samora Machel and this represented a great political event. The Italian Government itself directly became active in Mozambique, with the massive program of development cooperation, which we have mentioned above. Andreotti, for a long time Minister of Foreign Affairs and one of the most prominent members of DC, gave a great attention to the relations with East and Africa, focusing on Mozambique, as demonstrated by the many visits to the country he made, and by the support given to peace process. His purpose was to fit into the spaces that the great powers had left free in the international arena, as Cabaço remarked ${ }^{8}$. Going to Mozambique, to take office, the first italian Ambassador Claudio Moreno was accompanied by a small delegation of doctors, including Professor Pampiglione, Professor Cresta and Dr. Monasta that immediately were engaged in a support program in Maputo Central Hospital as well as in the Medicine Faculty of the University Eduardo Mondlane. The Italian position appeared to be completely different from that of other countries. Ambassador Claudio Moreno says that Italy was very well seen at governmental level. As a demonstration of it, he tells that, while at that time all the Mozambicans that held institutional positions, were not allowed to have relationships with Western embassies, they were not forbidden to

\footnotetext{
${ }^{8}$ L. Cabaço, quoted interview.
} 
have contacts with the Italian ${ }^{9}$. Later the "Tangentopoli” storm wiped out some of the protagonists of the first phase of cooperation with Mozambique, but it did not interrupt the relationship of solidarity between the two countries. The most relevant event showing the good relations existing between these two countries was registered in 1981, when President Samora Machel went to Rome on an official visit and was received at the Quirinale by President Sandro Pertini (Fondazione Sandro Pertini, 1981); Machel returned in Rome in 1985, and, on that occasion, was received by Pope John Paul II. The words of Mario Lanzafame, sum up the birth, institutionalization and strengthen of the ItalyMozambique cooperation:

... as solidarity... turns into cooperation, as activists in the labor movement, executives, professionals in the health field and administrators transformed the theory and practice of proletarian internationalism, as it was called, in solidarity at first and then in cooperation; as individual believers, militant in social Christian organizations, important Christian Democrat leaders made use of their government positioning to offer the opportunity of creating at first supportive relationships and then relationships linked to a more general framework of development models, as anti-colonialist and emancipation movements... build relations and connections, that leave deep traces to the present time: what they kept from the experience gained during the season of the struggle and what they left behind when they became leaders of their countries; as professionals or volunteers, individually at first and then in partnerships, built and put into practice solidarity, international cooperation and humanitarian intervention (Lanzafame, 2005).

Strong relationships were also created with many NGOs, among which the most active were Molisv and CUAMM, but also with IPALMO, that so much would have done in the birth and development of university cooperation in Mozambique. One of the highest points in the relationships between Italy and Mozambique is represented by the signing of the Rome Peace Agreement, in 1992, which, thanks to the mediation of the Catholic Church and Sant'Egidio Community, put an end to a civil war that had lasted 16 years. After the signing of the peace agreement, the UN sent international troops to Mozambique (Onumoz), to manage the peace transition (Couto, 2000), in which also Italian soldiers took part.

2) Italian universities did not have a strong tradition in the activity of international cooperation, especially with Africa. However, the cooperation with Somalia had obtained, as one of its best results, the opening of the Somali University. The political situation in Mozambique and its friendly relationship with the Italian Government made possible to develop some initiatives in this field. Mozambique needed technical assistance: socialist countries could not guarantee all these necessities, so Italy entered a space quite empty. Personal relations too had an important role. In 1976, together with the first Italian Ambassador, Moreno, some academic professors leaved to Mozambique, beginning to cooperate with this country, initially in the field of health and, from 1977, through programs of technical assistance with the Faculty of Geology. In 1978 the commitment of Italian academic cooperation involved other faculties, such as Agriculture, Economics, Medicine and Architecture. The Italian universities most involved in these first programs were Rome, Viterbo, Udine and Venice. In 1983, the first bilateral agreement of academic cooperation Italy-Mo-

\footnotetext{
${ }^{9} \mathrm{C}$. Moreno, quoted interview.
}

zambique was signed. These programs continue till today even if with some difficulties, due to the financial situation of Italy.

3) In the Seventies IPALMO played a relevant role in the building university cooperation. This institute has been defined as “... (a) kind of pressure group, a real aid lobby”, led by Piero Bassetti and Giampaolo Calchi Novati (Calchi Novati, 1997). The successes achieved in this specific field of cooperation, certainly persuaded the two parts to go on with the academic relationships. As a direct impact of this commitment on the country's development, it is possible to mention, the following areas in which the scientific international cooperation between Italy and Mozambique was carried out:

a) Geology: 10 square degrees of the provinces of Nampula, Zambézia and Cabo Delgado were cartographated, and a great quantity of petrographic, geological and geophysical data gathered. New areas of mining interest, the ones that only began to be exploited in the Nineties, were identified in the Seventies thanks to the Italian scientific cooperation. Hydro-geological maps of Maputo and Gaza provinces were produced.

b) Architecture: between 1996 and 2009, many studies were performed, among which: a survey on the Maputo corridor, the main road connection between Mozambique and South Africa; the analysis of the growth of urban centres and their suburbs; the classification of the architectural heritage of the country and, finally, the elaboration of town planning schemes referred to various cities, among which Matola. Rules for the civil constructions were defined. It is important to point out that the Architecture faculty of the Mondlane University eas established thanks to a direct partnership with the University of Rome, La Sapienza.

c) Agriculture: Both the "Sunflower Project" in South Mozambique, creating a new variety of sunflower, more suitable for the local climatic features and the experimentation on the njiemba bean, helped Mozambique to diminish its structural food deficit.

d) Medicine: an important research was published, at the end of a program aimed to study and identify the main characteristics of infectious diseases, such as enteritis, sexually transmitted diseases, otitis and parasitosis.

e) An international Centre of Biotechnology was set up, that has established itself as one of the most prominent centers of excellence in the area of applied sciences in Mozambique.

Also cases of failure were registered, such as the cooperation between the Faculty of Economics of the Eduardo Mondlane University and the Faculty of Economics of the "Tor Vergata" University in Rome, but they did not interrupt the scientific cooperation between the two countries.

4) The external factors. Besides inner factors, external reasons too contributed to the development of the relationship between Italy and Mozambique. At a geo-political level, in fact, Italy had tried, without success, to play a political and economic role in its former colonies. Its following step was, therefore, to "enter" the territories "belonging to weak colonial powers, as the relationships with the rest of the former colonial world was interdicted to us” as Gian Paolo Calchi Novati points out at the conference "L'Italia nell'era della colonizzazione e del neocolonialismo" (Calchi Novati, 1997).

According to this interpretation, Italy opportunistically "entered" the former Portuguese colony, due to the weakness of Portugal, as Ennio Di Nolfo stated in the above mentioned conference:

Mozambique, as the other Portuguese colonies, has been one 
of the privileged sectors for Italy, being naturally Portugal a weak power, and leaving to Italy the possibility or the hope to obtain here more vantages than in the other colonies belonging to France or Great Britain (Di Nolfo, 1997).

So, a very plausible reason for the italian commitment in the cooperation with Mozambique might be its attempt to create a zone of political and economic influence, considering the proximity of Mozambique to the former Italian colonies. Another external reason could be its position as a member of NATO. As Calchi Novati stresses:

Nato, and generally the East-West politics, gave Italy interesting chances for intervening in the international scenario. The simple fact to be part of the great Western democracies was considered a goal, or better, the only, real goal of our foreign politics effectively achieved (Calchi Novati, 1997).

This ability, from the Italian side, to insert its foreign strategy inside the framework of the Cold War and of the NATO too, permitted it to act according to a high level of originality and freedom. Adding the fact that Samora Machel, in spite of the marxist choice of the governament, was never willing to close international relations with the Western countries, it is then possible to explain the reason why these external factors approximated the two countries. Without former colonies towards which to direct its political strategy, Italy switched its attention to the areas of tensions rather than to those of stability (Romano, 2002).

\section{The Importance of Economic Factors}

Looking for the reasons that are at the basis of the Italian cooperation in Mozambique we cannot forget the economic aspects, which are many and long-standing, although for the most part, so far unknown.

To understand the importance of Mozambique for the Italian economy and the commitment of the Italian Cooperation in this country, we must go back to the period immediately after independence, in which many Italian companies were engaged in the building of important infrastructures.

The Corumana dam is the most important contract signed between Italy and Mozambique after independence. In 1982 the Banco de Moçambique made a financial agreement with Mediocredito bank for a 13 billion dollars loan for the building of the dam. The works were entrusted to the consortium Co.bo.co (Condotte d'Acqua, Bonifica-IRI, Lega delle Cooperative).

To the same period dates the construction of the Pequenos Libombos dam, whose building was entrusted to the Consorzio Strade-Italstrade and to the Calzoni Company. The total value of the works was of 110 million dollars for which Mozambique signed an agreement with Mediocredito bank (Repubblica, 10/7/1984:10).

Other Italian companies took charge, over the years, of the rebuilding of power lines (SAE/Sadelmi in the Centre-North, ENEL between Cahora Bassa and South Africa), aqueducts (CMB in Beira, CMC in Pemba), the railway line MaputoSwaziland (Consorzio IRSA-Ansaldo/Astaldi), roads (CMC and Astaldi), the completion of the first optic fiber telephone connection (Italtel). In recent years, Italy has had a role in Mozambican economy through ENI oil exploration and the cultivation of oil palm and jatropha for the production of fuels.

The great Italian works in Mozambique continued, even if on a smaller scale, during the nineties and the new millennium, until the inauguration, of the bridge over the Zambezi River, in 2009.
Although the works were carried out by a Portuguese consortium, the Italian company Trevi played an important role in its construction, having built the foundations of the pillars. Through their contributions the European Commission (€35 million), Italy (20 million) and Sweden (18 million), allowed making true the old Mozambican dream of joining the north and the south of the country, separated by the Zambezi River.

Italian cooperation in the infrastructure sector has never stopped: a project for the construction of the Nhacangara dam (in the province of Manica) for an amount of more than 60 million euro and the one for the drainage of a part of the city of Maputo are in progress. (Ministero Degli Esteri-Coopera-Zione Allo Sviluppo, 2012).

Currently the CMC OF Ravenna is in charge of the rehabilitation of the sewer system of Beira, Mozambique's second largest city, the building of highways and other civil works ${ }^{10}$.

In recent years, thanks to the continuation of the aid on the one hand and the investment growth on the others, the Italian presence in Mozambique has definitely strengthened and has been supported by the "Africa Plan" of the Ministry of Foreign Affairs and the Ministry of Economic Development (MISE).

From 2008, the will to create economic ties between the two countries, which also can take advantage of the thirtyfive-year friendship between Italy and Mozambique, has become pressing. There's the Italian intention to benefit from the position of the African country which has one of most promising economies in the SADC thanks to its vast natural resources not fully exploited yet (lo Cascio, 2010).

As a result of this renewed commitment, exports increased (compared to 2008) to more than 63\% (from 24 to 39 million euro, the highest value in the last ten years), placing Italy in the ninth position among Mozambique supplying countries (data 2009).

Simultaneously to the growth of exports, there has been a reduction in imports by $38 \%$, the Italian trade deficit thus passing from about 236 million to about 121 million (data 2010).

Cooperation has thus been an effective lever for raising and expanding the partnership between Rome and Maputo and to support the renewed interest of Italian companies in the Mozambican market.

Recently, moreover, the ENI research for oil and natural gas in northern Mozambique that began a few years ago, have borne fruit. At the end of 2011, the Italian oil company announced the discovery of a huge natural gas field off the coast of Cabo Delgado, estimated at 30 billion cubic meters, which could radically change Mozambican economy, creating at the same time, a major source of income for the Italian company (Daly, 2011; Smith, 2012; Garzilli, 2012): “... (the) greatest discovery of hydrocarbons that Eni has ever done... the increase $20 \%$ at one swoop of the world reserves of the six-legged dog, "as stated by the Eni CEO Paolo Scaroni (Il Sole 24 Ore, 21/10/2011).

The opening of a new phase of economic relations between the two countries as a result of the exploitation of natural gas fields discovered by ENI, not separated by the continuation of co-operation relationships, still required by the Mozambican government, was also outlined by the Italian Minister of Foreign Affairs Terzi, during his official visit to Mozambique on May

\footnotetext{
$\overline{{ }^{10} \mathrm{CMC} \text { has been in Mozambique since 1982, when the Pequenos Libombos }}$ dam was built and (under the name of CMC Africa Australe Lda.) is the greatest building company in the country employing 3.000 workers and with 100 million euro turnover. Source: "Il Sole 24 Ore" Speciale, numero 41, 17th October 2008, p. 27.
} 
4th, 2012 (Ministry of Foreign Affairs, 2012).

\section{Conclusion}

The here presented study intended to check the initial hypothesis, according to which the cooperation between Italy and Mozambique had an "atypical origin" denying, to some extent, the established paradigms in this respect. Actually, from the available data, it can be concluded that the reasons that usually lead European countries to engage in cooperative relationships with developing countries, do not apply to the Italian case, at least as regards the relationship with Mozambique.

The almost complete absence of a colonial history made so that Italy had to "create" areas of influence in the African context, which didn't take place neither through a planned project, nor, much less, through an "institutionalized" modality. The main way to enter Mozambique in a such massive manner has been through a "bottom up" strategy, thanks to the political relations of leftist Italian forces with FRELIMO in a first time, and then through the Catholic movements too. From the moment in which Mozambique gained independence from Portugal, its government established good diplomatic and bilateral official relations with Italy, taking advantage of all the political relationships developed throughout the years thanks to the activism of local institutions.

This led to a long period of cooperation, even if with limited economic benefits in comparison with the amount of the investments, as clearly indicated in the above study. However, the impacts on the scientific field have been relevant, since great progresses have been made in the knowledge of geology, agriculture, medicine, architecture and urban planning.

It is possible that the current situation will change this framework, as the ENI investment in Cabo Delgado gas seems to show. It would be quite interesting to understand if and how the strong bilateral relations between Italy and Mozambique have been able to open the doors to ENI, or if it has been the result of an independent activity of this great company. But this is another issue, which would need a new and different research.

\section{Acknowledgements}

A special thank to prof. Maurizio Vernassa, director of the $\mathrm{PhD}$ School in geopolitics at the University of Pisa, for the support given to this research, presented today in the journal AHS.

\section{REFERENCES}

Amin, S. (1977). Capitalism in the age of globalization. London: Zed Books.

Bertulli, C. (1974). Croce e spada in Mozambico. Roma: Coines.

Bussotti, L. (2011). Il Mozambico nella stampa italiana. Il caso de “L’Osservatore Romano"e de "La Repubblica”. In Bussotti/Ngoenha (Eds.), Le grandi figure dell'Africa Lusofona (pp. 127-160). Udine: Aviani.

Cabaço, L. (2003). La polvere e la pioggia. Maputo: Ambasciata d'Italia-Ufficio per la Cooperazione allo Sviluppo.

Calchi Novati, G. P. (1997). L'Italia nell'era della decolonizzazione e del neocolonialismo. Paper presented at the First Workshop CONICS, "La Cooperazione allo sviluppo nella politica estera italiana". Sala Morosini, Roma: Ministero Affari Esteri. http://www.uniurb.it/scipol/dmg.htm\#convegni

Cardoso, F. H., \& Faletto, E. (1979). Dependency and development in Latin America. University of California Press

Carrino, L. (2005). Perle e Pirati, Critica della cooperazione allo sviluppo e nuovo multi-lateralismo. Trento: Erickson.

ChillÀ, A. (1986). Mozambico al bivio fra miseria e convivenza pacifica (p. 3). L'Osservatore Romano.

Daly, J. C. K. (2011). Is Mozambique the Next African Energy Superpower? OILPRICE.COM.

http://oilprice.com/popup9.html

Di Nolfo, E. (1997). Cooperazione e politica estera: opzioni strategiche, opzioni geografiche. Paper presented at the First workshop CONICS, "La Cooperazione allo sviluppo nella politica estera italiana”. Sala Morosini, Roma: Ministero Affari Esteri. http://www.conics.it/word/atticonics.pdf

Frank, G. (1966). The Development of Underdevelopment. Monthly Review Press.

Gabas, J.-J. (2005). French Development Co-operation Policy. In P. Hoebink, \& O. Stokke (Eds.), Perspectives on European Development Co-operation. Oxon/New York: Routledge.

Garzilli, E. (2012). L'Italia in Mozambico: organizzazioni umanitarie e affari sui giacimenti di gas. Il Fatto Quotidiano.

Glisenti, M. (2003). La polvere e la pioggia. Maputo: Ambasciata d'Italia-Ufficio per la Cooperazione allo Sviluppo.

Grieco, J. M. (1988). Anarchy and the limits of cooperation: A realist critique of the newest liberal institutionalism. International Organization, 42, 485-507. http://dx.doi.org/10.1017/S0020818300027715

Il Sole 24 Ore, (2008). Numero Speciale, 41.

Lanzafame/Poliadri (2004). La stagione della solidarietà sanitaria a Reggio Emilia: Mozambico 1963-1977-Un esempio ante litteram di cooperazione decentrata. Torino: L'Harmattan Italia, Logiche Sociali.

Lanzafame, M. (2005). La stagione della solidarietà a Reggio Emilia: Mozambico e Africa Australe. http://www.boorea.it/Sezione.jsp?idSezione=32

Lo Cascio, C. (2010). Intervista per Newsletter Consorzio Italy.

Ministero Degli Affari Esteri (2013). Cooperazione Allo Sviluppo, Linee guida della cooperazione allo sviluppo per gli anni 20011. http://www.cooperazioneallosviluppo.esteri.it/pdgcs/documentazione /PubblicazioniTrattati/2011-01-01_LineeGuida20112013agg.pdf

Osce/Dac (2012). Dac Peer Review, Italy various years. Paris. http://www.oecd.org/

Pertini, S. (1981). Bibliografia degli scritti e discorsi di Sandro Pertini (1924-2007). voce n. 929: Discorso pronunciato il 14 ottobre 1981 nel palazzo del Quirinale a Roma, in occasione della visita ufficiale in Italia del presidente della Repubblica popolare del Mozambico Samora Machel, in SD II, 279-281. www.fondazionepertini.it

Raimondi/Antonelli (2001). Manuale di Cooperazione allo sviluppo. Torino: SEI.

Relazioni annuali sull'attuazione della politica di cooperazione allo sviluppo sul sito.

http://www.cooperazioneallosviluppo.esteri.it/pdgcs/italiano/pubblic azioni/intro.html

Romano, S. (2002). Guida alla Politica Estera italiana da Badoglio a Berlusconi. Milano: RCS Libri S.P.A.

Smith, D. (2012) Africa's resource curse throws shadow over Mozambique's energy bonanza. "The Guardian”, guardian.co.uk

Terzi, G. (2012). Intervento nella sua visita in Mozambico del 4 maggio. http://www.esteri.it/MAE/IT/Sala_Stampa/ArchivioNotizie/Approfo ndimenti/2012/05/20120504_Mozambico.htm

(2013). The End of Poverty: An Interview with Jeffrey Sachs. http://www.motherjones.com/politics/2005/05/end-poverty-interview -jeffrey-sachs

World Bank (2008). Beating the Odds: Sustaining Inclusion in Mozambique's Growing Economy. Washington.

http://econ.worldbank.org/external/default/main?pagePK=64165259 \&theSitePK=469372\&piPK=64165421\&menuPK=64166093\&entity ID=000334955_20080822070929 